\title{
The Existential World of George Oppen
}

\section{S. Dembo}

\section{I}

"I salute a serious craftsman," wrote Ezra Pound in his preface to Discrete Series, George Oppen's first volume, "a sensibility which is not every man's sensibility and which has not been got out of any other man's books." Oppen's sensibility is indeed not every man's but it is one that clearly belongs to its age. And he has turned out to be much more than a serious craftsman. Metaphysically inclined, even in the earlier imagistic pieces that Pound was describing, Oppen presents a stark but intense world in which nothing is certain but the sheer existence of nature and the pressure of feelings and sensations on the mind that encounters it.

From the beginning, imagism was, for Oppen, a cognitive as well as a formal technique: objects could only be known "imagistically," by one's sensation of them, and not discursively. 1 Thus Oppen sought to "construct a method of thought from the imagist ... intensity of vision," a method that would represent a "test of truth" or at least a "test of sincerity," based on the idea "that there is a moment, an actual time, when you believe something to be true, and you construct a meaning from those moments of conviction."

Discrete Series (1934) is in effect a Cartesian investigation by imagistic rather than rationalistic means. "A discrete series," Oppen explains, "is a series of terms each of which is empirically derived, each one of which is empirically true. And this is the reason for the fragmentary character of those poems. I was attempting to construct a meaning by empirical statements, by imagist statements."2 Imagist thought is a form of nominalism in which, to repeat, appreciation of the existence of the object in its tangibility replaces thought about the object:

It is still a principle with me, of more than poetry, to notice, to state, to lay down the substantive for its own sake. . . .

A statement can be made in which the subject plays a very little part, except for argumentation; one hangs a predicate on it that is one's comment about it. This is an approximate quotation from Hegel, who added . . . "Disagreement marks where the subject-matter ends. It is what the subject-matter is not." 3

Again, this approach corresponds to the nature of the world in general, for the world is "impenetrable"; the

Power and weight of the mind ... is nothing

And does nothing

Against the natural world. 
What is available to man, to the poet in particular, "Is that emotion/Which causes/To see"; possession of that emotion is the "true virtue of the mind." "I suppose it's nearly a sense of awe," says Oppen, "simply to feel that the thing is there and that it's quite something to see. It's an awareness of the world, a lyric reaction to the world."

In "The Mind's Own Place," Oppen argued that the particular contribution of modern poetry lay in the fact that the "data of experience," "the sense of the poet's self among things," replaced "a display of right thinking and right sentiment, a dreary waste of lies." Political or other generalizations "will not substantiate themselves in the concrete material of the poem"; rather poetry intends to present "clear pictures of the world in verse which means only to be clear, to be honest, to produce the realization of reality, and to construct a form out of no desire for the trick of gracefulness, but in order to make it possible to grasp, to hold the insight which is the content of the poem."4

Oppen was not, however, insensitive to the difference between truth and sincerity. While the poet aimed to be empirical, the best he could be in actuality was true to his own perceptions-not necessarily true to the thing as it was but true to it as encountered. The poet was a "reporter," but, paradoxically, a reporter of his own perceptions and feelings. One might go so far as to say that, broadly speaking, Oppen's reasoning is phenomenological: since consciousness is consciousness of an object, rigorous investigation of one's consciousness provides knowledge about the object. This logic lies behind the epigraphs to The Materials and This in Which:

'... Are you trying to describe the creation of the world-the universe?' 'What else?'

$\therefore$. I asked for an explanation of the things that have just happened to us.'

'I told you that you would not like the explanation.'

-Robert A. Heinlein

'... the arduous path of appearance.'

-Martin Heidegger

We awake in the same moment to ourselves and to things.

-Maritain

They fed their hearts on fantasies

And their hearts have become savage.

The Heidegger quotation comes from the discussion of Being and Appearance (Introduction to Metaphysics) and involves an interpretation of Parmenides' idea of the three paths to a knowledge of reality. Along the third, "the arduous path of appearance," reality (the "essent") "looks now thus and now otherwise. Here only opinions prevail. Men slide back and forth from one opinion to another. They mix being and appearance." What is important, however, is that the ex- 
perience of this path is required for a total knowledge. It is necessary for the man entering on the path to Being (the first path) " to experience everything. . . . you should also learn how appearance persists in appearingly drawing (in its own way) through all things, contributing to complete all things.'" The third way is thus "experienced as belonging to being."5 For Oppen, appearance is what is seen, and what is seen intensely, as far as the poet is concerned, is. This is what Oppen means when he asserts his faith in the reality of the perceived world, while remaining wholly aware that his vision may have significance only to himself.

It is not surprising, then, to find Oppen asserting that he has "a sense . . . of the greater reality of certain objects than of others." For example, a "car closed in glass" strikes him as being unreal,
At the curb,
Unapplied and empty:
A thing among others
Over which clouds pass and the alteration of lighting. . . .

(The feeling is no doubt ethical as well as epistemological.) An apt contrast to this poem is one that deals with the experience of sailing, a sport to which Oppen was addicted:

\author{
The mast \\ Inaudibly soars; bole-like, tapering: \\ Sail flattens from it beneath the wind. \\ The limp water holds the boat's round \\ sides. Sun \\ Slants dry light on the deck. \\ Beneath us glide \\ Rocks, sand, and unrimmed holes. ${ }^{6}$
}

Needless to say, what is important here is the intensity of physical sensations, particularly of sight and the sense of motion. "There is a feeling of something false in overprotection and overluxury," Oppen said of the closed car; correspondingly, there must be a feeling of something genuine in the act of sailing, although it is crucial that the sensations speak for themselves.

The aesthetic qualities of objects or even events-objects apprehended not in terms of their associations or conventional significance but in terms of their form or motion-are the qualities that are taken to be "empirical," even though that empiricism is relative to the poet. Notice the structure of this poem:

Bolt

In the frame

Of the building-

A ship 
Grounds

Her immense keel

Chips

A stone

Under fifteen feet

Of harbor

Water-

The fiber of this tree

Is live wood

Running into the

Branches and leaves

In the air.

The essence of this poem is in the poet's perspective. Noticing an infinitesimal detail on a building construction, imagining a grounded ship to be (delicately?) chipping a stone, and considering the complexity of a section of a tree are all expressions of that "virtue of the mind which causes to see."

A more interesting (and more obscure) experiment in perception appears in a poem in which the speaker is explicitly concerned with modes of observation. Again, it is perspective that controls the description:

Who comes is occupied

Toward the chest (in the crowd moving opposite

Grasp of me)

In firm overalls

The middle-aged man sliding

Levers in the steam-shovel cab,-

The mention of the age of the steamshovel operator is perhaps an accidental, human concern in a scene otherwise chiefly a matter of gesture and motion:

Lift (running cable) and swung, back

Remotely respond to the gesture before last

Of his arms fingers continually-

Turned with the cab.

At this point the poem breaks as the poet tries to adjust his vision and see beyond the cityscape:

\author{
it?)- \\ But if I (how goes \\ The asphalt edge \\ Loose on the plateau, \\ Horse's classic height cartless ...
}


As Oppen explains it, the poet's eye sees plain land, the prairie that preceded the city and on which the city "loosely" stands; he imagines a horse in this natural environment. But apparently the vision is momentary and the poem concludes with another urban object:

See electric flash of streetcar,

The fall is falling from electric burst.

Although he said that the technique here was one of montage, Oppen felt that the poem was, finally, incoherent. It is true that the lines presenting the vision of the prairie are elliptical and, without Oppen's explanation, incomprehensible; nonetheless, there is something to be said for the fact that this vision is scarcely distinguishable from the other observations. The poem is rendered coherent by the presence of a single kind of sensibility: one for whom the objects in its view possess equal "reality." The prairie and horse, though imagined, exist as "presences" no less tangible to the perceiver than a steamshovel or a streetcar. To call them presences, however, is not to put them in the category of fantasies, or better their origin is natural not supernatural, psychological not psychic. To Oppen, primitive reality is, if anything, more substantial than the realities of civilization.

Despite his virtues, the poet, like all men, is limited in what he can see and know. One of the most important poems on this theme is the last one Oppen wrote before his long silence, a brief, esoteric piece called "Party on Shipboard:"7

Wave in the round of the port-hole

Springs, passing,-arm waved, Shrieks, unbalanced by the motion-

Like the sea incapable of contact

Save in incidents ( the sea is not water)

Homogeneously automatic-a green capped white is momentarily a half mile out-

The shallow surface of the sea, this,

Numerously-the first drinks-

The sea is a constant weight

In its bed. They pass, however, the sea

Freely tumultuous.

Oppen explained the work by saying that "one sees separate waves, but the sea is there; one sees separate people, but humanity is there. Out of separate incidents, one tries to make a picture of what the sea is or humanity is." This logic is, of course, profoundly nominalistic: one can know only particulars and hope to build a meaning from them. The "concept of humanity" was one such meaning that Oppen was hoping to validate in "Of Being Numerous."

What Oppen seems to be doing in this poem is presenting the perceptions of a revelling poet, for whom both the party and the ocean outside have become 
a blur. The fact is, however, that drunk or sober he is still limited to the laws of nominalist or imagistic thought; namely, that the people or the sea are "incapable of contact save in incidents"-that he must see "numerously" (waves) instead of wholly (the sea). An intimation of what the sea really is comes when it is felt as "a constant weight/In its bed," but this insight gives way to the overwhelming passage of waves and to their general tumult.

Similar limitations of perception are characterized in a poem dealing with the "mystery of place," a recurrent theme in Oppen's later work. The problem of the isolated, objectivist perceiver is again paramount when the poet, viewing a town from a train window, reflects on the sense of environment of one of the citizens:

Town, a town,

But location

Over which the sun as it comes to it;

Which cools, houses and lamp-posts

during the night, with the roads. . . .

From a train one sees

him in the morning, his morning;

Him in the afternoon, straightening-

People everywhere, time and the work pauseless:

One moves[,] between reading and re-reading,

The shape is a moment.

The intimacy of the townsman with his town is a phenomenon that the passenger can only reflect upon, not "feel" or truly "know." The very description in the poem is, characteristically, "objective": made up of discrete particulars that reflect the impersonality of an observer and a stranger whose view is momentaryitself a contrast with the endless process of townlife known by the citizen. In the last three lines a girl enters the scene and, as can be expected, she is perceived "empirically":

From a crowd a white powdered face,

Eyes and mouth making three-

Awaited-locally-a date.

For all its limitations, however, this kind of observation is the most empirical and the most "sincere"; it represents without mitigation the "actual experience" of a poet who is committed to his eyes and refuses to fabricate an emotion or to "construct a meaning" that is fanciful. The poet perceives reality from a rocking boat or a moving train-sometimes a cause of despair, sometimes a cause of joy, but always a fact of life to a man of integrity.

Poems like those just cited suggest that "the virtue of the mind which 
causes to see" is not always fulfilled or fulfilled in such a way that the observer's sense of isolation is only increased. For example, the opening poem in Discrete Series speaks of the knowledge of boredom being the knowledge

Of what, Maud Blessingbourne it was, wished to know when, having risen,

"approached the window as if to see what was really going on";

And saw rain falling, in the distance more slowly,

The road clear from her past the windowglass-

Of the world, weather-swept, with which one shares the century.

(Maud Blessingbourne is a character in Henry James' short story, "The Story in It." Reading a French novel while her hostess is writing letters, Mrs. Blessingbourne "breaks the tension" of silence by getting up, looking at the fireplace, and out at the rain. Oppen has alluded to her chiefly because of the line "as if to see what was really going on," and the reference really has no further relation to the story.) "The knowledge of the mood of boredom," said Oppen, "is the knowledge of what is, 'of the world, weather-swept.' " He went on to mention his sympathy with Heidegger, who, in his acceptance speech for the Chair of Philosophy at Freiburg in 1929, used "as a philosophic concept a mood of boredom." In that speech, translated as "What Is Metaphysics," Heidegger has argued that boredom, as well as "the joy we feel in the presence of the being . . . of someone we love," "reveals what-is in totality." In "Of Being Numerous" Oppen was to write of "The boredom which disclosed/Everything." But it is clear that Maud Blessingbourne is experiencing the "contingency" of what-is and Sartre's description of Baudelaire goes a long way toward explaining the metaphysical significance of her mood: "He was attracted by the idea that things are thoughts which have been objectified and, as it were, solidified. In this way he could see his own reflection in them; but natural realities had no significance for him. They meant nothing; and the disgust and boredom which overcame him in face of the vague, mute, disorderly monotony of a landscape were no doubt among the most immediate reactions of his mind."8 For Oppen, the attempt to acquire knowledge about "what is/really going on" can only end in ennui, for nothing is going on that is reducible to meaning. Aesthetic joy or intellectual depression are the two basic responses to bare reality.

\section{II}

In Oppen's three major volumes, The Materials (1962), This in Which (1965), and Of Being Numerous (1968), the "empiricism" of Discrete Series reaches social and cosmic dimensions. How things are perceived remains fundamental in the later poems, but the range of experience becomes much broader, and a prophetic 
note enters the voice of the imagist. Still rigorously "reporting" only what he himself feels or knows, Oppen describes a universe.

The years Oppen spent in Mexico, where he fled in 1950 to avoid testifying before the McCarthy Committee, established or intensified a personal sense of exile that underlies his whole vision. "Return," one of the few relatively long poems in The Materials, begins with a feeling of place that has been denied the poet:

This Earth the king said

Looking at the ground;

This England. 9

Contrasting with this sense of the solid and the known, is the poet's awareness of the fluidity and flux of his own world:

\author{
But we drive \\ A Sunday paradise \\ Of parkway, trees flow into trees and the grass \\ Like water by the very asphalt crown \\ And summit of things \\ In the flow of traffic. ... \\ The noise of increase. . . . (10)
}

The city to which the speaker has returned is unfamiliar and remote, its change reflecting the lack of continuity between his own past and present. He sees buildings razed in the streets where he had once known the vicissitudes of the Depression, experiences that constituted his life. He is no less intensely aware of his own isolation and indeed the mutual isolation of all men; the "noise of increase" means mere numbers, not community:

We cannot reconcile ourselves.

No one is reconciled, tho we spring

From the ground together . . . (10)

The poet recalls the visit to a museum in which he saw a Sequoia seed compared to "the tremendous slab of the tree" itself:

And imagined the seed

In soil and the growth quickened

So that we saw the seed reach out, forcing

Earth thru itself into bark, wood, the green

Needles of a redwood until the tree

Stood in the room without soil-

How much of the earth's

Crust has lived

The seed's violence! 
In a poem called "Sara in Her Father's Arms," Oppen referred to an infant as a "little seed,/Little violent, diligent seed." and he asked "What will she make of a world . . . of which she is made." The "violent" Sequoia seed is also made out of the world (earth), though the museum tree stands "without soil." A clue to the meaning of this passage appears in "Blood from the Stone," a title that signifies the idea of "life/From a stone dead dam. Mother/Nature!" Because nature is dead, man is "deserted" and has only himself to ease his loneliness in the world. The Sequoia, one might argue, is a form of life that exists totally "in the singular" and, perhaps, "lone in a lone universe . . . suffers time/Like stones in sun" ("Birthplace: New Rochelle"). "Men do not," and it is in their children that they seek fulfillment. Or, it would be better to say, Oppen seeks fulfillment in his own child:

\section{Mary,}

Mary, we turn to the children

As they will turn to the children

Wanting so much to have created happiness

As if a stem to the leaves .... (11)

Furthermore, the child in its innocence has a possibility for communion that the literally and spiritually exiled adult can never experience:

-we had camped in scrub,

A scrub of the past, the fringes of towns

Neither towns nor forest, nothing ours. And Linda five,

Maybe six when the mare grazing

In the meadow came to her.

Learning welcome. . . .

Little girl welcomed,

Outside of this kind of experience, life is perhaps limited to "remote/Mechanics, endurance." And the perpetual renovation of the city, with its destruction of the pasts of individual men, suggests that even endurance, if it is to be associated with continuity rather than mere durability, is almost impossible. "How imagine it?" asks the poet, seeking to reconstruct the lost surroundings of his earlier years,

Of streets boarded and vacant where no time will hatch

Now chairs and walls,

Floors, roofs, the joists and beams,

The woodwork, window sills

In sun in a great weight of brick. (12)

It is no coincidence that the recollection of the past most vivid to him is the image of a mother-figure, Petra, who beats "A washpan out of her window 
gathering/A crowd like a rescue. Relief,/As they said it, The relief. Petra,/Decisive suddenly among her children." Contrasting with the stone dead dam, Mother Nature, Petra, for all her literal reality, seems to represent the impulse toward community and family, the eros that makes human beings more than objects. That this impulse is constantly negated, that community and even family are no more than conceptions that men require for survival, is one of Oppen's chief themes. His past includes not only people like Petra but those like Father Coughlin, Pelly, and the Silver Shirts, pre-War American Fascists. The poem does not imply, then, that the past is any better or worse than the present. The real question is, Is home recoverable to the exiled man? The answer seems to be that the poet must seek to recover his past in the full knowledge that he cannot succeed, the "must" being a psychological rather than an ethical compulsion.

The estrangement of the poet from the world is no more profound than his estrangement from himself. If he is what he sees and experiences ("What I've seen/Is all I've found: myself"-"Product"), his "self" shares the nature of objects: to be alien and familiar at once. Thus in a dream the poet sees

An old man's rounded head

Abruptly mine

Self-involved, strange, alien, The familiar flesh

Walking. I saw his neck, his cheek

And called, called:

Called several times.

(“Resort," 7)

Actually the poem implies nothing. The poet has simply entered his own field of observation (a distant volcano and a "tree in leaf here" have perhaps inspired the dream); the "meaning" of his own image is as remote and inaccessible as that of other particulars. As I have suggested, Oppen is much more the phenomenologist than the depth-psychologist. The source of consciousness is man's existence among objects; “Thought leaps on us' because we are here," he writes in "World, World" (This in Which). "Soul-searchings" are merely an attempt to "lose oneself in the mystical self." The truth, however, is that the "self is no mystery, the mystery is/That there is something for us to stand on."

"Myself I Sing," elaborating the theme of "Party on Shipboard," presents a view of the self that is both nominalistic and phenomenological. On the road, the poet has encountered the owner of a trailer, who, by simply referring to himself, stimulates the poet to meditation:

Me! he says, hand on his chest.

Actually, his shirt.

And there, perhaps,

The question. (19) 
The poet tries to answer the question by "constructing a meaning," an identity, from the particulars:

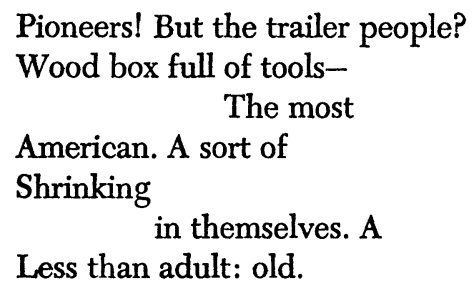

A pocket knife,

A tool- (19)

But like the sea, "humanity" (if it indeed exists) is "incapable of contact/Save in incidents;" the self (if it exists) expresses itself only through fragmentary particulars, and is, finally, unknowable. In any case, the poet cannot utter the word "myself" with any of the naive assurance of the trailer owner, for, in keeping with a basic principle of phenomenology, "myself/Is what I've seen and not myself." 10

Because he cannot "know" others, the sense that he must have of himself is that of "a man marooned," who

No longer looks for ships, imagines

Anything on the horizon. On the beach

The ocean ends in water. (19)

Suffering the "shipwreck of the singular" ("Of Being Numerous"), the poet can, again, know the ocean only as water ("the sea is not water," says "Party on Shipboard") and take solace in the power of his imagination. Yet just as he has a momentary awareness of "the constant weight of the sea in its bed," and intimation of the whole beyond the "incidents," so the poet is subject to intimations of a common humanity beyond the fragmentary encounters by which men are confirmed in their isolation:

And yet at night

Their weight is part of mine.

For we are all housed now, all in our apartments, The world untended to, unwatched.

And there is nothing left out there

As night falls, but the rocks (20)

In "Bahamas" (This in Which) Oppen presents the complaint of a tourist who is screened off from the primitive realities of the place he is visiting, the essential one being the "Haitian boats/Which bear their masts . . . across the miles/Of the Atlantic, and the blinding glitter/Of the sea." To see with a tourist's eye, 
rather than know the primitive, is perhaps the fate of the poet, for whom, as for all men, "the world, if it is matter,/Is impenetrable." An elaboration of the theme implicit in the poem in which the speaker views a town from a train appears in "Tourist Eye," an imagist's response to New York. The unstated question in this longer poem is, What can be "empirically" known from viewing the architecture? For example, in viewing the Lever Brothers' building, one is compelled to ask, "What is the final meaning/Of extravagance?" The tourist can scarcely speculate on the significance of the "thousand lives/Within that glass," nor on the multitudes in apartment houses, "the living, that other/Marvel among the mineral." Confronted by the enormous and the numerous, he can only in vain look "For something bequeathed/From time,"-again, something that will reveal the presence of "humanity." The music that he hears from within a structure "rearing/Black windows into daylight" all the more accentuates his sense of meaninglessness:

\section{the sound}

Of a piano in the deep bulk tying Generations to a Sunday that holds, As the building holds, only the adamant

Nothing that the child hopes, Laboring a tune. (28)

Yet as another poem, "The Source," implies, there is something inside the tenement:

In some black brick

Tenement, a woman's body

Glows. . . .

The City's

secret warmth.

It is impossible to say whether this is a proof that humanity exists or whether it is simply another "lyric valuable," a presence that fills the speaker with joy or awe although he cannot fathom its meaning.

In the same way, visiting the Red Hook section of Brooklyn, the poet seems to discover something bequeathed from time and to see momentarily with more than a tourist's eye:

The heart pounds

To be among them, the buildings,

The red buildings of Red Hook!

He responds to the ferries, the tides of Buttermilk Channel, and the hardware 
stores, as well as to the homes of the "aging workmen," all of which represent the "essential city,/The necessary city." In "Red Hook: December," a later poem, Oppen wrote, "one can be at peace/In this city on a shore/For the moment now/ With wealth, the shining wealth" (of Christmas lights). Yet this response is almost wholly aesthetic, a matter not of insight but of feeling. And characteristically for Oppen the feeling is qualified; one can be at peace for the moment, for the city, like the world, is as dangerous as exhilarating. "This is the sense of order/ And of threat," comments the poet in "Tourist Eye" and he concludes with a powerful sense of menace engendered by headlines of violence. The point of the poem, however, is that to the eye of the poet-tourist the city is buildings and crowds, both being objects that are, in effect, out there. In quest of a "concept of humanity" he seems doomed, except for rare and fragile occasions, to a vision of numbers.

The vision of the city-dweller himself is, needless to say, scarcely more penetrating than that of the tourist. In "Vulcan" we find that the "householder issuing to the street/Is adrift a moment in that ice stiff/Exterior." Like the poet, who in Discrete Series sees the prairie beneath the asphalt, he has a momentary intuition of the city's past as a "Peninsula/Low lying in the bay/And wooded." His current reality, however, is not the forest, but the subway station, where he sees a crippled girl sitting quietly among the workers repairing the rails. This environment, which "contains/Labor before her birth, her twisted/Precarious birth," is, Oppen seems to imply, her native setting. Here are the concluding bizarre lines:

Slowly,
Deliberately she sees
An anchor's blunt fluke sink
Thru coins and coin machines,
The ancient iron and the voltage
In the iron beneath us in the child's deep
Harbors into harbor sand.

Questioned about the meaning of these lines, Oppen replied that the girl is simply being "pulled down by the anchor." Whatever the case, the crippled girl, with her "iron" fate, seems to be a daughter of Vulcan. But what is more interesting is that this whole view of the girl is a product of the householder's state of mind:

We have not escaped each other,

Not in the forest, not here.

We shift our eyes.

$$
\text { .. . painfully }
$$

He is aware of a human responsibility, but he finds himself helpless, and his compassion or sentiment is transformed into a response in keeping with a concrete and metallic reality. That he should imagine the girl seeing the anchor 
tells us more about the speaker than her actually seeing the anchor tells us about the girl. For the speaker is projecting his own reality upon her: "adrift a moment in that ice stiff/Exterior," he tries to stabilize himself with the vision of a vernal land; adrift in an equally rigid interior, he seeks to get his bearings with a mythological vision. He himself is trying to sense the primitive reality ("child's deep harbors") beneath the mineral fact, the unconscious beneath the conscious, and the past beneath the present. But all this is mere conjecture, and all that can be said with certainty is that the poem evades sentiment. It remains empirical as far as the speaker's feelings are concerned, at the same time confirming the self-acknowledged failure of the poet to arrive at a valid concept and sense of humanity.

If one of the moving principles of Oppen's philosophy is that human illusions and generalizations cannot pass the rigorous poetic "test of truth," an equally important principle is that men are compelled to believe certain things in order to survive; the poet knows this to be so because he himself must believe in the unverifiable; the very quest for a concept of humanity, for instance, is one such "real" compulsion. If people knew the world was going to end in a given length of time, Oppen argued, "they would not bother to live their time out. There are other situations any of us could imagine in which people would not be willing to live, would find it impossible to live, without some concept of sharing in history or humanity-something which is happening after their death." 11 This notion appears in "Image of the Engine," a poem concerned with immortality, community, and love. The first section of this elliptical work begins with the description of a worn out engine in operation. "When the thing stops," asks the poet,

\author{
will one imagine \\ Then because he can imagine \\ That squeezed from the cooling steel \\ There hovers in that moment, wraith-like and like a plume \\ of steam, an aftermath, \\ A still and quiet angel of knowledge and of comprehension. (2)
}

Oppen explained that he was conceiving man as a machine who possibly had a ghost. But he emphasized the question, "will one imagine?" ("Shall we imagine because we can imagine?" he asked.) Man has an impulse to believe in a spirit after life because it's difficult to believe in death, as the second part of the poem makes clear:

The image of the engine

That stops.

We cannot live on that.

I know that no one would live out

Thirty years, fifty years if the world were ending

With his life. 
Then Oppen completes the analogy set up in the first section by actually going on to imagine what the spirit of the engine would, if it existed, comprehend or perceive:

The machine stares out,

Stares out

With all its eyes

Thru the glass

With the ripple in it, past the sill

Which is dusty-If there is someone

In the garden!

Outside, and so beautiful. (3)

This description curiously resembles the way in which the poet himself perceives when he is exercising the "virtue of the mind," the emotion that "causes to see." Perhaps we have come full circle here: the "life of the mind" in which the poet is intensely aware of the aesthetic "presence" of things is itself a concept that serves as antidote to the sense of mortality. The impulse to believe that man has a soul that survives him, that the machine has a spirit that is "conscious" after the machine has stopped, is not far from the impulse to believe that the Empirical Man, the realist in a fatal world, has a special aesthetic sense and an awareness of mystery-in short, a poetic nature-that justifies his existence.

In any case the next two sections return to the realities of the fatal world itself, or in the language of Wallace Stevens, to the world without Imagination. The essence of that world is shipwreck ("all embarkations/Foundered"). In cold reality, no spirit stares out at a garden; rather a mindless gull stares blankly at a sinking ship:

On that water

Grey with morning

The gull will fold its wings

And sit. And with its two eyes

There as much as anything

Can watch a ship and all its hallways

And all companions sink. (4)

The shipwreck is that of human intimacy and love, for we learn in the final section that

Also he has set the world

In their hearts. From lumps, chunks,

We are locked out: .... (5) 
The impersonal, the inert, the mineral fact is in everyman and foredooms to mortality all close relationships. "With their first full strength/The young go search for it [love]," but even they outgrow their emotions, which end in "a grimy death of love."

The fate of human dreams, illusions, and desires-as the fate of men themselves-is to return to the lumps and chunks of the inert matter of the world:

Glitter of the stores!

The lost

The streets of stores!

Crossed by the streets of stores

And every crevice of the city leaking

Rubble: concrete, conduit, pipe, a crumbling

Rubble of our roots (5)

But if love dies, the compulsion to love and be loved does not; desire survives all shipwreck:

\section{But they will find}

In flood, storm, ultimate mishap:

Earth, water, the tremendous

Surface, the heart thundering

Absolute desire. (5)

This is not, of course, a sentimental reaffirmation of the power of love. The heart thunders desire in precisely the same way as floods or storms occur; desire is simply a fact, an absolute, in men's experience; men are made of the world. On the other hand, desire and love do transform them and confirm their humanity. Although the poem describes the machine as a "Hot lump . . ./Geared in the loose mechanics of the world," Oppen explained that when the motor started, it was "very different from a lump of steel." Like the motor, the human heart and mind are made of matter, but in their vitality, impermanent as it is, they are something more.

Human constructions, mental or physical, transistory or relatively durable, are, as with Stevens, a mode of creating order in a contingent and fatal universe. For Oppen, the carpenter or craftsman exists in the known:

\section{Speaking of things}

End-for-end, butted to each other,

Dove-tailed, tenoned, doweled-Who is not at home

Among these men? who make a home

Of half truth, rules of thumb

Of cam and lever, and whose docks and piers

Extend into the sea so self-contained. ("The Men of Sheepshead," 34) 
Or, again, men put together reality like a jigsaw puzzle:

The jigsaw of cracks

Crazes the landscape but there is no gap,

No actual edged hole

Nowhere the wooden texture of the table top

Glares out of scale in the picture,

Sordid as cellars, as bare foundations. ... ("The Solution," 8)

It is the architecture of Chartres, not the sculpture of the facings, that makes it a monument to the desire for permanence and continuity

\section{Supports another}

That the stones

Stand where the masons locked them

Above the farmland

Above the will ("Chartres," 40)

Such stones, the materials of the world, are the means by which men create their own objects. Ironically, the adornments on Chartres, the images of "Mary the woman and others," emblems of compassion, are merely "dreams on the structure," and the cathedral, with its "bulk in the air," shares with other matter an impenetrability that, irrespective of any religious associations, inspires awe. Man's eyes, "The Little Hole" (This in Which) tells us, have exposed him naked to the world;

\section{Blankly the world \\ Looks in}

\section{And we compose}

Colors

\section{And the sense}

Of home. . . .

Yet what is home but the impenetrable earth? The sense of home is paradoxically the sense of exile; if men refashion reality, being creatures of reality themselves, they cannot meaningfully depart from their prototype. Chartres is both a refuge, and an enormous bulk; the colors that men compose are serene, we may suppose, but also "so violent/And so alone/They cannot rest." 
As many of the poems in This in Which indicate, art is not good for men unless "like the fool persisting in his folly" it "rescues" him "as only the true might" ("From Virgil"). And poetry is the language of faith in the material world and the means for expressing its ultimate mystery. In the short but central poem called "Psalm," in which the expression "this in which" appears, Oppen presents an epitome of his poetics and metaphysics. Here the speaker observes some deer and in typical nominalist fashion responds to the simple fact of their existence: "That they are therel" He notices their eyes, "soft lips," and "alien teeth" as they graze "in the strange woods," and concludes:

Their paths

Nibbled thru the fields, the leaves that shade them

Hang in the distances

Of sun

Crying faith

The small nouns

In this in which the wild deer

Startle, and stare out. ${ }^{12}$

When asked what the nouns were crying faith in, Oppen responded in Heideggerian terms:

Well, that the nouns do refer to something; that it's there, that it's true, the whole implication of those nouns; that appearances represent reality, whether or not they misrepresent it: that this in which the thing takes place, this thing is here, and that these things do take place. ${ }^{13}$

Oppen argued that in uttering small words like "sun" and "shade" one was implying an entire cosmos. "It's a tremendous structure to have built out of a few small nouns. I do think they exist . . . it's certainly an act of faith. . . . In 'Psalm' I was constructing what I felt to be a pretty emotional poem out of those few little words isolating the deer." The This In Which is, then, the natural world, strange and unknowable, but certainly to the man of faith who perceives its aesthetic presence, there. ${ }^{14}$ Again, the poet demonstrates his faith by uttering nouns, forms of speech that signify the existence of the object but provide no knowledge about it. As "The Building of the Skyscraper" asserts,

There are words that mean nothing

But there is something to mean.

Not a declaration which is truth

But a thing

Which is. (73) 
The full significance of "Psalm" is made clear by explicit thematic statements such as the one that concludes the "Narrative" suite. The encounter with Beingthe deer and their setting-is an example of the "life of the mind," other than which "there is no life for humanity." Although men are a part of the earth ("River of our substance/Flowing/With the rest"), "the mind rises/Into happiness, rising/Into what is there. I know of no other happiness. . ." (82) In this sense, the isolated man is at home in his exile:

\author{
Islands \\ To the north \\ In polar mist \\ In the rather shallow sea- \\ Nothing more \\ But the sense \\ Of where we are
}

Who are most northerly. (82)

Here the poet breathes "the open/Miracle/Of place" and experiences an absolute: "I thought that even if there were nothing/The possibility of being would exist;/I thought I had encountered/Permanence." And again, the language appropriate to an experience of Being is the poetry of nouns, a "substantial language/Of clarity, and of respect" (my italics). By clarity Oppen meant "Transparence,/I don't mean that much can be explained./Clarity in the sense of silence" ("Of Being Numerous," \#22): the noun refers; it does not try to define, and because it does not, it preserves the speaker's respect for the inviolability of the subject.

That the islands in the polar mist could have inspired the poet with dread and the sense of Néant, as well as with joy and the sense of Being, points up the dualism of Oppen's view. The life of the mind coexists with angst, boredom, and despair as simply another aspect of reality. On the one hand,

The power of the mind, the

Power and weight

Of the mind which

Is not enough, it is nothing

And does nothing

Against the natural world,

The fatal rock ... (“Of Being Numerous, \#26”)

On the other, as we have seen, Oppen believes that "there is no life for humanity except the life of the mind." The unifying element in this view is the principle 
that reality in all its manifestations is to be respected as "truth." "Non-truth" for Oppen-or better, a lesser degree of reality-is represented by the closed car, the luxurious guest room ("Guest Room"), or Wildenstein's opulent art gallery. "Giovanni's Rape of the Sabine Women at Wildenstein's" brings these attitudes together.

The statue of Giovanni da Bologna, enacting the rape of a young girl by a Roman soldier, as he steps over the figure of a cowering old man (presumably the girl's father), stands futilely in its luxurious surroundings, "Thick carpeted, exhilarated by the stylish/Or the opulent, the blind and deaf." For Oppen the work seems to represent the condition of life: the soldier emblemizes the violence of What Is; the girl emblemizes the human response to it. It is "a difficult/Song/ Full of treason," treason perhaps because it celebrates and aesthetically renders destructive forces rather than providing a sentimental comfort. The girl herself is "betrayed" by the artist intent on celebrating Reality since she herself is portrayed as

Seeking like a child the eyes

Of the animals

To promise

Everything that matters, shelter

From the winds

'Powerless to affect

The intensity of what is'-(34)

Such a portrayal all the more affirms the artist's commitment to reality and makes his work, itself an Object, too intense for the superficial audience to whom it is displayed.

Observing the statue, the poet is moved to meditate on his own response to What Is and he imagines its positive qualities; Oppen again chooses to use sea and wind imagery:

We sailed in it, the large

Loose sphere of it

Visible, the force in it

Moving the little boat. (35)

Yet the winds are after all "ruinous" and the poet feels "the long helplessness/Of those who will remain in it/And the losses." A possible implication here is that the speaker is expressing a human sympathy with the girl and is therefore himself committing "treason/To the artists." That is, he is wavering in his faith in or his obligation to Truth: 
one needs such faith,

Such faith in it

In the whole thing, more than I,

Or they, have had in songs.

Perhaps even the artists most faithful to reality have, like the speaker, been unable to praise it fully.

This dualistic attitude lies behind the esoteric "Philai te kou philai" ("Loved and Not Loved"), the subject of which, Oppen explained, is "Mother Earth," or, once more, the Real. The setting of the poem is a lake, "in the bend of the parkway," on which the poet is rowing with a companion, and the two figures are "Lost in the childish ... / /among the primitive toys/Of vacation, the circle of the visible." The circle of the visible, said Oppen, has become in the civilized world a mere toy of vacation, not what it was to the primitive, who was aware of the tremendous presence of all Nature around him. "It's just a game to pretend that only the tree within sight is present." Reality is not only Nature, however, but any of the vast, impersonal forces or objects in the world. A terrified animal signifies the primitive in nature, but it also leads the speaker to meditate on the technological realities that are in their own way no less tremendous and "primitive" than natural forces:

What entered the mind

When dawn lit the iron locomotives,

The iron bridges at the edge of the city,

Underpinnings, bare structure,

The animal's bare eyes

In the woods .... (18)

Reality is what is and what has happened: "the relation of the sun and earth" beyond the circle of the visible, the "sea in the morning," and the "hills brightening." It is also history and the social and psychological condition of men. The day that breaks upon the sea and the locomotives also breaks upon the million

Windows and the grimed sills

Of a ruined ethic

Bursting with ourselves, and the myths

Have been murderous. ... (18)

And finally Reality is past civilizations:

Rococo boulevards 
Backed by the Roman

Whose fluted pillars

Stand on other coasts

Lifting their tremendous cornices. (19)

Exactly what the ruined ethic is (perhaps humanism) is not so important as the simple fact that man has reason to love and hate the earth and that there is no end ("Where can it end?"), or for that matter, meaning, to the process that determines his fate. Men's myths and ethics, far from saving him, have only increased his misery, since they have been perishable or destructive. (Oppen must have had Christianity in mind for he mentions "Stake/And faggot.")

As a contrast to the modern vacationer Oppen presents the image of the 19th-century "Intellectual," as idealized in a painting by Thomas Eakins. "This was his world," the poet declares, suggesting that perhaps this man was able to see beyond the circle of the visible, and to respond to it with the proper "seriousness." The image is particularly obscure, however, and it is possible that since Oppen was interested in Eakins as a "realist" painter, the portrait, with its "masculine drama," "glitter of . . . eyeglasses," and "firm stance" was meant to be taken as part of the Real World or at least as being in harmony with it.

IV

Oppen's meditative long-poem, "Of Being Numerous," and its sequel, "Route," clarify and elaborate, rather than add to, the themes and techniques of the preceding volumes. As its title indicates, the former is concerned with individuality and "numerosity," again the question, as Oppen put it, of whether there is such a thing as humanity. The sequel is about "the learning that one is, after all, just oneself and in the end is rooted in the singular, whatever one's absolutely necessary connections with human history are."15 Both poems, then, mingle autobiography and metaphysics-or rather, as is the essential feature of Oppen's vision, investigate the metaphysical implications of one's own experiences and, conversely, the experiential basis of one's philosophic generalizations.

Opening with the now-familiar proposition that "There are things/We live among and to see them/Is to know ourselves" the poem embarks on an inquiry into the nature of men's lives in the city. (Many of the sections are taken from "A Language of New York" in This In Which.) The things among which we live are "sad marvels," the "mineral facts" of skyscrapers, that can be seen but not comprehended. In a sense, the city merely exists; it has no meaningful or recoverable past; accordingly life in general is mere "Occurrence/a part/Of an infinite series." The poet finds himself incapable of living in any time but the present. Even markers of the past, for example a stone in the pylon of a bridge bearing the inscription "1875," far from affording a sense of continuity, have only the effect of contingent objects upon the observer: 
Frozen in the moonlight

In the frozen air over the footpath, consciousness

Which has nothing to gain, which awaits nothing, Which loves itself (\#5) 16

The poet is, however, aware of his own individuality; objects like the marker, in fact, confirm his feelings of isolation. Again, it is quite probable that Oppen's literal exile and sense of discontinuity ("The Return") lie behind this universal appraisal. Whatever the case,

The isolated man is dead, his world around him exhausted

And he fails! He fails, that meditative man! (\#10)

And perhaps a personal sense of shipwreck gives force to the abstraction:

Obsessed, bewildered

By the shipwreck

Of the singular

We have chosen the meaning

Of being numerous. (\#7)

The Singular Man had the power of seeing intensely, but not of communicating; the shipwreck of the singular is really the failure of the poet to fulfill himself outside the community. On the other hand, there is a question as to whether any community actually existed. The metropolis can never return to the primitive ideal:

Families talked,

They gathered in council

And spoke, carrying objects.

They were credulous,

Their things shone in the forest. (\#12)

To the contrary, the modern city is predicated on argument:

They develop

Argument in order to speak, they become

unreal, unreal, life loses

solidity, loses extent . . . . (\#13) 
But the poet

$$
\text { ... wants to say }
$$

His life is real . . . .

It is not easy to speak

A ferocious mumbling, in public

Of rootless speech (\#17)

Yet because he "cannot even now/Altogether disengage myself" from the men with whom he served in the war, he continues to believe in the possibility that there are "men" rather than simply "The People'/Who are that force/Within the walls/Of cities" (\#14).

The true struggle in the poem is that of the poet with himself. "We want to defend/Limitation/And do not know how," he asserts. And the reason that he does not know how is that he cannot consistently believe in the "metaphysic" that will transform the infinite series of single lives into continuity and community, "the metaphysic/On which rest/The Boundaries/Of our distances." (\#26) Generations succeed one another only to be lost, Oppen implies, in "the great mineral silence/. . . a process/Completing itself." Against the "fatal rock/Which is the world," men can pose only their ability to see. Salvation for the poet lies only in his sense of joy or awe at what he observes:

$O$ if the streets

Seem bright enough,

Fold with fold

Of residence . . .

Or see thru water

Clearly the pebbles

Of the beach

Thru the water, flowing

From the ripple, clear

As ever they have been (\#26)

Thus:

Only that it should be beautiful,

Only that it should be beautiful,

O, beautiful .... (\#32)

This is our jubilation

Exalted and as old as that truthfulness

Which illumines speech. (\#33) 
Tho the world

Is the obvious, the seen

And unforeseeable,

That which one cannot

Not see

Which the first eyes

Saw .... (\#36)

The poem accordingly ends with a quotation from Whitman in which the capitol dome at sunset is described: "it dazzles and glistens like a big star: it looks quite . . . . curious . ..." "At the end of a very long poem," Oppen remarked, "I couldn't find anything more positive to say than that." The "first eyes" can be bedazzled but all they know is "the noon's/own vacuity" (\#36); the anticlimactic comment marks the sum of the poet's knowledge of what he beholds.

Underlying the meditations on love, war, poetry, humanity, and personal experience in "Route" is the profound determinism that marks the whole range of Oppen's work. Love is essentially a biological phenomenon, a matter of chromosomes and genes; it "occurs," no less impenetrable an event than any phenomenon of nature:

The sources

And the crude bone

-we say

Took place

Like the mass of the hills. (\#1)

To look into oneself, one must outward to "Reality, blind eye/Which has taught us to stare." What is perhaps the poet's own love is best defined in imagistic and aesthetic, not personal and sentimental, terms:

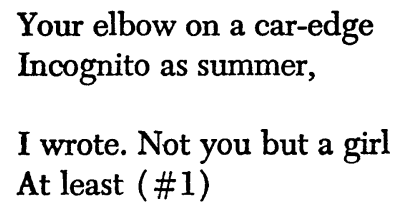

Aesthetic clarity is the chief quality of poetry, which as we have seen, merely signifies and delimits:

I might at the top of my ability stand at a window

And say, look out; out there is the world. (\#3) 
... One man could not understand me because I was saying simple things; it seemed to him that nothing was being said. I was saying: there is a mountain, there is a lake

A picture seen from within. The picture is unstable, a moving picture, unlimited drift. Still, the picture exists. (\#6)

The picture is unstable because "Things alter, surrounded by a depth and width."

The story about the Alsatian men who hid themselves in holes to avoid conscription into the Nazi army (\#5) was actually told to Oppen and therefore is part of the poet's experience. Aside from its pathos, by which Oppen was deeply moved, it is, in its understated irony and matter-of-fact tone, part of the poet's "reportage" of the way men behave and the way things occur. That is, the real subject is the strength of authentic feelings; I don't believe that Oppen is trying to comment on the horrors of war. Authentic feelings, "absolute desire," are the psychological realities that are prior to all human constructions, ethics included:

Wars that are just? A simpler question: In the event, will you or will you not want to kill a German. Because in the event, if you do not want to, you won't. (\#6)

And:

We are brothers, we are brothers?-these things are composed of a moral substance only if they are untrue. If these things are true they are perfectly simple, perfectly impenetrable, those primary elements which can only be named. (\#6)

If brotherhood is a moral principle, it is "untrue"; to be true, it must be in the genes and chromosomes-"those primary elements"-wherefore, it can only be signified and not understood. Consistent with his psychological or biological determinism, Oppen views war not as a manifestation of evil per se, but rather as a form of insanity ("Of Being Numerous," \#18-20). And if the genes do not produce love, "we will produce no sane man again" ("Route," \#1).

Although Oppen provides instances from his own experiences, his personality never really emerges in the poem. It is, of course, completely logical that it should not. Since, to repeat, the self exists only in terms of physical realities and forces, and these elements are impenetrable, the self stands perpetually unrevealed, if it can be said to exist in the first place. The events of the poet's life are glimpsed fragmentarily and constitute an infinite series of particulars, leading finally to death, not a meaningful whole:

I remember my father as a younger man than I am now, My mother was a tragic girl

Long ago, the autonomous figures are gone,

The context is the thousands of days ("Route," \#9) 
In a world of overwhelming numerosity of persons, things, and days the poet seeks a "limited, limiting clarity" (\#1). In its ultimate sense, the shipwreck of the singular is the failure to realize the finite and to achieve true Clarity. "The mind creates the finite" (\#11) and clarity is part of the emotion that causes to see, but, as we have been told in "Of Being Numerous," the power of the mind "is nothing/And does nothing" against "The fatal rock/Which is the world." "We want to defend/Limitation/And do not know how" ("Of Being Numerous," \#26). On the other hand, if a man does not despair, "he sees in the manner of poetry" ("Route," \#8). Perceptual joy as well as conceptual boredom is possible, and "the lyric valuable" is obtainable. But perhaps even the lyric valuable will not be sufficient if Reality deprives men of the love necessary for sanity and they are faced with "Cataclysm . . . cataclysm of the plains, jungles, the cities." "Route," as well as Oppen's vision in general, ends in an apprehension of the "void eternally generative," of the space that is vivaparous in the time of the missile ("Time of the Missile"), those

things at the limits of reason, nothing at the limits of dream, the dream merely ends, by this we know it is the real

That we confront

\section{NOTES}

1 For an account of Oppen's relations to the so-called Objectivist movement, see "The 'Objectivist' Poet: Four Interviews" (Oppen, Carl Rakosi, Charles Reznikoff, and Louis Zukofsky), along with my introduction, in Contemporary Literature, $\mathrm{X}$ (Spring 1969). I have also touched upon the subject in a review of Oppen's Pulitzer prize-winning volume, Of Being Numerous, in The Nation (November 24, 1969). The review also contains general biographical information. With permission of The Nation I have incorporated certain passages from this work into the current discussion.

2 Interview, p. 161.

3 Ibid., p. 161-2. The reference to Hegel is particularly illuminating. Oppen seems to be drawing upon the conception of "Sense-certainty," the lowest form of consciousness outlined in Phenomenology of the Mind. In the words of one expositor, J. N. Findlay, "Sense-certainty is the most emptily abstract of consciousnesses: its whole content can be covered by such bald phrases as "There is this" or simply "It is." To say anything more about what confronts us in Senseawareness is at once to pass beyond it, to dissolve it into a series of concepts or universals, with which step the solidity of our knowledge will at once suffer an attenuation." (Hegel: a Re-examination [Collier Books, 1962] 88.)

4 Kulchur, III, 10 (Summer, 1963), 2-8, passim.

5 Martin Heidegger, An Introduction to Metaphysics, tr. Ralph Manheim (Doubleday Anchor Books, 1961), p. 95.

6 In Discrete Series (The Objectivist Press, 1934). The volume is unpaginated and lacks a table of contents for the thirty-odd, mostly untitled, poems.

7 An account of the reasons for Oppen's twenty-five year silence (approximately 1934 to 1959) appears in the interview and review, v.s.

8 Jean-Paul Sartre, Baudelaire, tr. Martin Turnell (New Directions, 1967), p. 104. 9 The Materials (New Directions/San Francisco Review, 1962) 10. Copyright 1960, 1961, 1962 by George Oppen. Succeeding page references, unless otherwise noted, are to this volume. All quotations are by permission of New Directions Publishing Corporation and the San Francisco Review.

10 Strictly speaking, it was Sartre, not Husserl, who totally eliminated the ego from consciousness. (See Sartre's The Transcendence of the Ego.) Husserl retains the ego as a unifying principle for perceptions. 
11 Interview, p. 166.

12 This in Which (New Directions/San Francisco Review, 1965) 20. Copyright 1962, 1963, 1964, 1965 by George Oppen. Succeeding page references, unless otherwise noted, are to this volume. All quotations are by permission of New Directions Publishing Corporation and the San Francisco Review.

13 Interview, p. 163.
14 Recall the Hegelian idea of Sensecertainty (footnote 3 , above).

15 Interview, p. 172.

16 Of Being Numerous (New Directions/ San Francisco Review, 1968). Copyright 1967, 1968 by George Oppen. References are to section numbers. All quotations are by permission of New Directions Publishing Corporation and the San Francisco Review.

from SOME SAN FRANCISCO POEMS (1969-1971)

\section{The Translucent Mechanics}

Combed thru the piers the wind

Moves thru the clever city

Not in the doors but the hinges

Finds the secret of motion

As tho the hollow ships moved in their voices, murmurs

Flaws

In the wind

Fear fear

At the lumber mastheads

And shouting fetched a message out of the sea again

Say angel say powers

Obscurely 'things

And the self

Prosody

Sings

In the stones

to entrust

To a poetry of statement

At close quarters 